\title{
Spatial distribution of non-point source nitrogen in urban area of Beijing City, China
}

\author{
Xiaowen Ding ${ }^{1,2,3^{*}}$, Yongwei Gong ${ }^{1}$, Chunjiang $\mathrm{An}^{3}$ and Ming $\operatorname{Lin}^{2}$
}

\begin{abstract}
Background: Non-point source (NPS) pollution, has been dominant in many urban areas, causing nutrient loss, water body pollution and aqueous systems damaging. Among the pollutants, nitrogen is a key nutrient which can cause eutrophication of rivers, lakes and reservoirs. Beijing, the capital of China, has a booming economy and a huge population. Various human activities have affected nitrogen accumulation deeply and caused considerable NPS pollution. This research calculated the annual load of NPS nitrogen in urban area of Beijing City (UABC) in 2005 and simulated its spatial distribution, which may be useful for environmental planning and pollution control of the $U A B C$ and cities with intensive human activities.

Results: The total NPS nitrogen load of the UABC was is $1083.09 \mathrm{t}$ in 2005. The load of agricultural land, construction land and unused land were 92.04 t, $969.29 \mathrm{t}$ and $21.77 \mathrm{t}$. As far as spatial distribution is concerned, construction land was with heavy pollution. Chaoyang district, Haidian district and Fengtai district were the most major export regions of NPS nitrogen loads. The loads of them were $376.88 \mathrm{t}$, $286.87 \mathrm{t}$ and $249.92 \mathrm{t}$. As for load intensity of NPS nitrogen, the high-load sources were distributed in the Xicheng district and Dongcheng district, of which the load intensities were $1.10 \mathrm{~km}^{2} / \mathrm{t}$ and $1.11 \mathrm{~km}^{2} / \mathrm{t}$ respectively. Among agricultural land, construction land and unused one, the high-load source was distributed in construction land.
\end{abstract}

Conclusions: Therefore, exhaust gas emission should be reduced, and roof greening as well as road sweep should be improved.

Keywords: Spatial distribution; Non-point source; Nitrogen; Urban area of Beijing city

\section{Background}

With the effective control of point source pollution, Non-point source (NPS) has become the major cause of water pollution in many countries, such as the UK (Whitehead et al. 2007), China (Ding et al., 2010) and the USA (Emili and Greene 2013). For rivers and lakes in urban areas, NPS pollution in the form of runoff from urban areas has contributed greatly to the degradation of flow in the receiving water bodies (Sartor et al. 1972; Kang et al., 2013). NPS pollution in urban areas has become an important issue for aquatic environments and

\footnotetext{
* Correspondence: binger2000dxw@163.com

${ }^{1}$ Key Laboratory of Urban Stormwater System and Water Environment, (Beijing University of Civil Engineering and Architecture), Ministry of Education, No.1 Zhanlanguan Road, Beijing 100044, People's Republic of China

${ }^{2}$ Key Laboratory of Regional Energy and Environmental Systems Optimization, Ministry of Education, North China Electric Power University, No. 2 Beinong Road, Beijing 102206, People's Republic of China Full list of author information is available at the end of the article
}

has therefore received increased attention in recent years (Rossi et al., 2006; Kang et al., 2013). NPS pollution in urban areas is not easily identified and characterized which adds significantly to the issues of source analysis, load calculation, and distribution simulation. Spatial distribution simulation in the typical urban area has its great importance of revealing the impact method of human activities on water pollution quantificationally.

Therefore, researches on NPS pollution in urban areas have been done in the fields of the runoff monitoring (Wada et al., 2006; Krometis et al., 2007), load simulation (Ward \& Dudding, 2004; Brown \& Peake, 2006; Duzgoren et al., 2006), and pollution control (Chimney \& Pietro, 2006; Kang et al., 2006). Beijing City is the capital of China, in which water pollution caused by NPS pollution is increasingly outstanding (Jing, 2008; Wang, 2011). The Urban area of Beijing City (UABC) is the core zone of Beijing and with very intensive human activities. Intensive human activities together with torrential 
Table 1 Area and population of the UABC in 2010 (Leading group office of Beijing sixth national population census, Beijing Municipal Bureau of Statistics, Beijing survey office of National Bureau of Statistics of China 2011)

\begin{tabular}{|c|c|c|c|c|c|}
\hline No. & $\begin{array}{l}\text { Administrative } \\
\text { region }\end{array}$ & $\begin{array}{c}\text { Area } \\
\left(\mathrm{km}^{2}\right)\end{array}$ & $\begin{array}{l}\text { Percent } \\
\text { of the } \\
\text { area (\%) }\end{array}$ & $\begin{array}{l}\text { Population } \\
\text { (million } \\
\text { person) }\end{array}$ & $\begin{array}{c}\text { Percent } \\
\text { of the } \\
\text { population (\%) }\end{array}$ \\
\hline 1 & Dongcheng district & 50.53 & 0.30 & 0.92 & 4.69 \\
\hline 2 & Xicheng district & 41.86 & 0.25 & 1.24 & 6.34 \\
\hline 3 & Chaoyang district & 455.08 & 2.71 & 3.55 & 18.08 \\
\hline 4 & Haidian district & 430.73 & 2.56 & 3.28 & 16.73 \\
\hline 5 & Shijingshan district & 84.32 & 0.50 & 0.62 & 3.14 \\
\hline 6 & Fengtai district & 305.80 & 1.82 & 2.11 & 10.77 \\
\hline 7 & UABC & 1368.32 & 8.14 & 11.72 & 59.74 \\
\hline 8 & Beijing city & 16807.80 & 100.00 & 19.62 & 100.00 \\
\hline
\end{tabular}

rains cause NPS become a major pollution source of receiving water bodies in the UABC. Studies on NPS pollution in the UABC have been also done on pollutant monitoring, component analysis and water quality assessment of runoff, as well as strategies on stormwater use and pollution control. The result indicated that NPS has become an important factor affecting urban water environment due to heavy rains and increasing impervious surface areas during the process of urbanization (Jin, 2008; Wang, 2011). Main NPS pollutants in the UABC were organic pollutants, nutrients and suspended solids (Che et al., 2002). Pollutant concentrations in rainfallrunoff were high in the early stage, especially in the first 40 minutes. Then the pollutant concentrations decreased, and reached stable values finally (Wang, 2004). Water qualities in rainfall-runoffs of various land use types were in different levels. That of grassland was better than that of land for roofed buildings, which was also superior to that of road (Liu et al., 2008). Pollution control of initial stormwater was significant for water environmental protection and stormwater utilization in the UABC (Liao et al., 2007).

It can be found that researches have been done mainly focus on field monitoring, establishing the relation between rainfall-runoff and pollution, and putting forward countermeasures and suggestions. Temporal scales of the researches focused on single or multiple storms, and spatial scales were only several monitoring sites. Researches on numerical calculation of annual load, its spatial simulation and its characteristic analysis of the UABC have not been reported. However, numerical simulation and distribution analysis in macro spatial-temporal scale is significant, which may provide more efficient and feasible decision support for pollution control and stormwater use.

\section{Methods}

\section{Study area}

Urban area of Beijing City, covering an area of $1368.32 \mathrm{~km}^{2}$, is located in the northwest of the Huabei Plain, and accounts for $8.14 \%$ of the entire area of Beijing City (See Table 1 and Figure 1). The administrative region of UABA contains Xicheng district, Dongcheng district, Chaoyang district, Haidian district, Shijingshan district and Fengtai district (See Figure 1). It is the most developed area in the city and has a very high population density (8562 per square kilometer). About 59.74 percent of

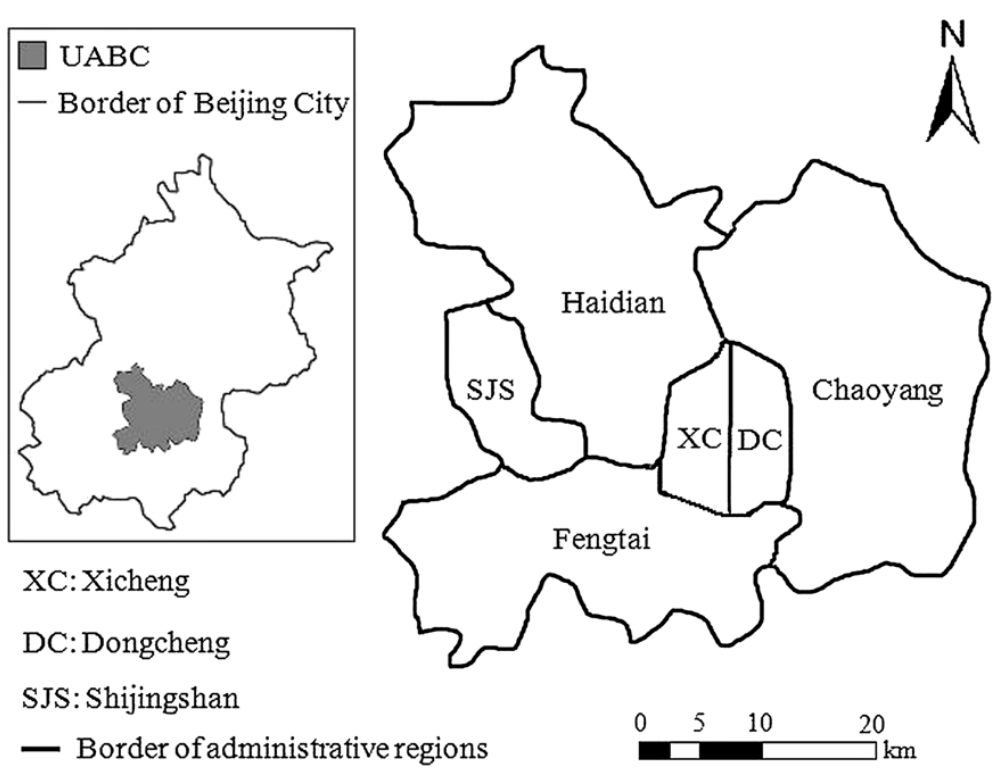

Figure 1 Map of the research area. 
the city's population lives in UABC even though it accounts for much less percent of the city's area. Due to its special geographic location and atmospheric circulation pattern, torrential rain occurs frequently in summer over the UABC. Moreover, rainfall is the main driving force of NPS contamination, which leads to serious NPS pollution occurrence in the study area.

\section{Model description}

The export coefficient model (ECM), which is based on the idea that the nutrient loads exported from a watershed equals the sum of the losses from individual sources, has been used in many studies. The model allows accurate estimation and analysis of nutrient pollutants (Johns, 1996). The ECM is outlined as:

$$
L=\sum_{i=1}^{n} E_{i}\left[A_{i}\left(I_{i}\right)\right]+p
$$

where $L$ is loss of nutrients $(\mathrm{kg}), E_{i}$ is export coefficient for nutrient source $i\left(\mathrm{t} / \mathrm{km}^{-2}\right.$ year $\left.^{-1}\right), A_{i}$ is area of the catchment occupied by land use type $i\left(\mathrm{~km}^{2}\right), I_{i}$ is the input of nutrients to source $i(\mathrm{~kg})$, and $p$ is the input of nutrients from precipitation $(\mathrm{kg})$. The ECM model has been applied in several watersheds, but no research is reported for a total urban area.

\section{Data collection and preparation}

Taking into account the research needs and data availability, the database for this research is as presented in Table 2. The land use map of 2005 was interpreted from the Thematic Mapper image provided by Beijing municipal people's government, China. The interpreted land use of the UABC was classified into agricultural land (plough, garden plot, woodland, grassland, and other farmland), construction land (land for roofed buildings, road, independent industrial and mining area, land for transport, and land for water conservation facilities), as well as unused land. The area of the UABC occupied

Table 2 Available data for the UABC

\begin{tabular}{lcl}
\hline Type & \multicolumn{1}{c}{ Scale } & \multicolumn{1}{c}{ Source } \\
\hline Land use & $1: 1500000$ & $\begin{array}{l}\text { RS image digitalizing and } \\
\text { interpreting, Beijing municipal } \\
\text { people's government, China }\end{array}$ \\
Landform & $1: 250000$ & $\begin{array}{l}\text { National geomatics center } \\
\text { of China }\end{array}$ \\
Administrative division & $1: 1500000$ & $\begin{array}{l}\text { Beijing municipal bureau } \\
\text { of statistics }\end{array}$ \\
Social economics & Each district & $\begin{array}{l}\text { Beijing municipal bureau } \\
\text { of statistics } \\
\text { Literature, statistical data, } \\
\text { and field monitoring }\end{array}$ \\
\hline
\end{tabular}

Table 3 Areas of various land use types in the UABC

\begin{tabular}{llccc}
\hline No. & District & \multicolumn{3}{c}{ Areas of various land use $\mathbf{( k m}^{\mathbf{2}}$ ) } \\
\cline { 3 - 5 } & & $\begin{array}{c}\text { Agricultural } \\
\text { land }\end{array}$ & $\begin{array}{c}\text { Construction } \\
\text { land }\end{array}$ & $\begin{array}{c}\text { Unused } \\
\text { land }\end{array}$ \\
\hline 1 & Xicheng & 0.00 & 50.53 & 0.00 \\
2 & Dongcheng & 0.00 & 41.86 & 0.00 \\
3 & Chaoyang & 146.60 & 299.27 & 9.21 \\
4 & Haidian & 207.93 & 215.46 & 7.34 \\
5 & Shijingshan & 32.84 & 48.37 & 3.12 \\
6 & Fengtai & 88.67 & 193.25 & 23.87 \\
7 & UABC & 476.03 & 848.75 & 43.54 \\
\hline
\end{tabular}

by various land use types were obtained from the interpreted land use map which was digitized and evaluated in each grid (see Table 3). The input of nitrogen from precipitation was determined by monitoring data which was considered as an average value in the different land use types. The layer of export coefficient was related to each spatial unit and those coefficients were determined.

\section{Determination of the export coefficient}

The export coefficients were derived from literature sources as well as calibration using the hydrology and water quality data. An approach has been developed based on the mass balance of the pollutant to determine the export coefficients of different land use types (Ding et al., 2010).

First, the export coefficient of a specific land use type was defined as $E_{i},(i=1,2,3, \ldots, n)$, with $n$ land use types. Next, $m$ small sub-watersheds $(m>n)$ are chosen from the entire research area and the NPS pollution

Table 4 Export coefficients of NPS nitrogen sources in the $\operatorname{UABC}\left(\mathbf{t} / \mathrm{km}^{2} \cdot \mathrm{yr}\right)$

\begin{tabular}{llc}
\hline Land use & \multicolumn{1}{c}{ Nitrogen source } & Export coefficient \\
\hline Agricultural land & Plough & 0.23 \\
& Garden plot & 0.08 \\
& Woodland & 0.20 \\
& Grassland & 0.30 \\
& Other farmland & 0.15 \\
Construction land & Land for roofed buildings & 1.09 \\
& Road & 1.33 \\
& Independent industrial and & 1.31 \\
& mining area & 1.41 \\
& Land for transport & 1.10 \\
Unused land & Land for water conservation & 0.50 \\
\hline
\end{tabular}




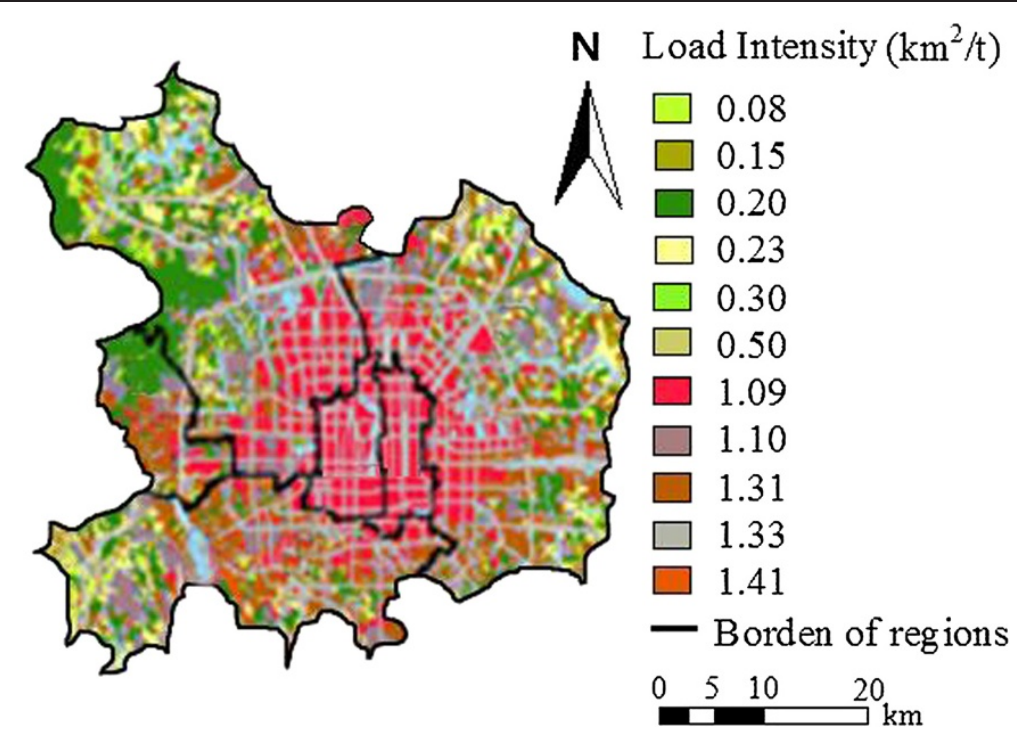

Figure 2 Spatial distribution of NPS nitrogen pollution of the UABC (2005).

yield equation for each sub-watershed is established as follows:

$$
L=P S+\sum_{i-1} E\left[A_{i}\left(I_{i}\right)\right]_{i}^{+} p
$$

where $L$ is the loss of nitrogen $(\mathrm{kg}), P S$ is the point source pollution load $(\mathrm{kg}), E_{i}$ is export coefficient of land use type $i\left(\mathrm{~kg} / \mathrm{km}^{2} \cdot \mathrm{yr}\right), A_{i}$ is area of land use type $i$ $\left(\mathrm{km}^{2}\right)$, and $I_{i}$ is annual input load of the NPS pollutants from land use type $i(\mathrm{~kg})$.

The left side of Eq. (2) can also be expressed as:

$$
L=\frac{C \cdot Q}{k}
$$

where $C$ is the annual mean observed concentration of the NPS pollutants in the outlet of the sub-watershed $(\mathrm{g} / \mathrm{L}), Q$ is the annual total stream flow measured in the outlet $\left(\mathrm{m}^{3}\right)$, and $k$ is the loss coefficient of the NPS pollutants in the sub-watershed.

Table 5 Spatial distribution of NPS nitrogen in different administrative regions (2005)

\begin{tabular}{llcc}
\hline No. & \multicolumn{1}{c}{ District } & $\begin{array}{c}\text { NPS nitrogen } \\
\text { load (t) }\end{array}$ & $\begin{array}{c}\text { Percent of the total } \\
\text { load of UABC (\%) }\end{array}$ \\
\hline 1 & Xicheng district & 55.62 & 5.14 \\
2 & Dongcheng district & 46.35 & 4.28 \\
3 & Chaoyang district & 376.88 & 34.80 \\
4 & Haidian district & 286.87 & 26.49 \\
5 & Shijingshan district & 67.46 & 6.23 \\
6 & Fengtai district & 249.92 & 23.07 \\
7 & UABC & 1083.09 & 100.00 \\
\hline
\end{tabular}

With $E_{i}$ set as unknown, the other parameters on the right side of Eq. (2) can be calculated as follows:

$$
P S=\frac{C_{d} \cdot Q_{d}}{D_{a} \cdot k} \times 365
$$

where $C_{d}$ is mean observed concentration of the NPS pollutants during the dry season in the outlet of the subwatershed $(\mathrm{g} / \mathrm{L}), Q_{d}$ is total flow volume during the dry season at the outlet $\left(\mathrm{m}^{3}\right)$, and $D_{d}$ is the number of days in the dry season.

Then, Eq. (2) can be transformed to:

$$
\frac{C \cdot Q}{k}=\frac{C_{d} \cdot Q_{d}}{D_{d} \cdot k} \times 365+\sum_{i=1}^{n} E_{i}\left[A_{i}\left(I_{i}\right)\right]+p
$$

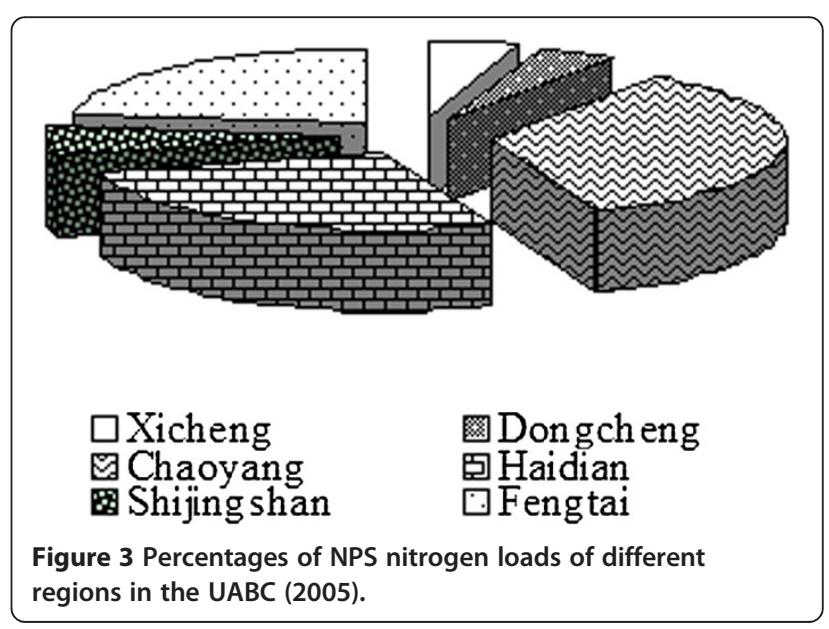


Table 6 Spatial distribution of NPS nitrogen loads in different land use types (2005)

\begin{tabular}{|c|c|c|c|}
\hline \multicolumn{2}{|r|}{ Type of land use } & \multirow{2}{*}{$\begin{array}{c}\begin{array}{c}\text { NPS } \\
\text { nitrogen } \\
\text { load (t) }\end{array} \\
29.47\end{array}$} & \multirow{2}{*}{$\begin{array}{c}\begin{array}{c}\text { Percent of } \\
\text { the total load } \\
\text { of UABC (\%) }\end{array} \\
2.72\end{array}$} \\
\hline Agricultural & Plough & & \\
\hline & Garden plot & 4.47 & 0.41 \\
\hline & Woodland & 43.93 & 4.06 \\
\hline & Grassland & 6.62 & 0.61 \\
\hline & Other farmland & 7.55 & 0.70 \\
\hline \multirow{7}{*}{$\begin{array}{l}\text { Construction } \\
\text { land }\end{array}$} & Land for roofed buildings & 743.24 & 68.62 \\
\hline & Road & 40.01 & 3.69 \\
\hline & $\begin{array}{l}\text { Independent industrial } \\
\text { and mining area }\end{array}$ & 68.01 & 6.28 \\
\hline & Land for transport & 112.17 & 10.36 \\
\hline & $\begin{array}{l}\text { Land for water conservation } \\
\text { facilities }\end{array}$ & 5.85 & 0.54 \\
\hline & Unused land & 21.77 & 2.01 \\
\hline & UABC & 1083.09 & 100.00 \\
\hline
\end{tabular}

With the analysis described above, we can obtain $m$ equations for the $m$ sub-watersheds, and the following equation group is established:

$$
\left\{\begin{array}{l}
\frac{C_{1} \cdot Q_{1}}{k_{1}}=\frac{C_{d 1} \cdot Q_{d 1}}{D_{d 1} \cdot k_{1}} \times 365+\sum_{i=1}^{n} E_{i}\left[A_{i 1}\left(I_{i 1}\right)\right]+p_{1} \\
\frac{C_{2} \cdot Q_{2}}{k_{2}}=\frac{C_{d 2} \cdot Q_{d 2}}{D_{d 2} \cdot k_{2}} \times 365+\sum_{i=1}^{n} E_{i}\left[A_{i 2}\left(I_{i 2}\right)\right]+p_{2} \\
\frac{\dddot{C}_{m} \cdot Q_{m}}{k_{m}}=\frac{C_{d m} \cdot Q_{d m}}{D_{d m} \cdot k_{m}} \times 365+\sum_{i=1}^{n} E_{i}\left[A_{i m}\left(I_{i m}\right)\right]+p_{m}
\end{array}\right.
$$

The export coefficient, $E_{i}$, for the different land use types can be deduced through optimization using the Genetic Algorithm (GA) and are listed in Table 4.

\section{Results and discussion}

Annual load of NPS nitrogen

Annual load of NPS nitrogen pollution was 1083.02 ton in 2005 and most of it occurred with urban storm. In terms of the hydrological term scale, 80 percent of the NPS nitrogen pollution concentrated in wet period (June, July and August). Therefore, it can be found that nitrogen loss is positive correlation with the rainfall, which indicates that NPS nitrogen pollution accumulates in dry seasons and occurs in wet seasons with rainfall and soil erosion.

\section{Spatial distribution of NPS nitrogen in different regions}

By geographic information system (GIS), the spatial distribution of NPS nitrogen load in the UABC in 2005 is simulated as Figure 2 shows.

The spatial distribution of NPS nitrogen load in different administrative regions is shown in Table 5. The percentages of NPS nitrogen loads of different administrative regions are shown in Figure 3. It can be found that Chaoyang district, Haidian district and Fengtai district are major regions carrying NPS nitrogen loads, while the NPS nitrogen loads in other districts are relatively low. The main reason is that the areas of the three districts are much larger than the other ones.

\section{Spatial distribution of NPS nitrogen in various land use types}

As for various land use types, spatial distributions of NPS nitrogen loads in them are shown in Table 6. The percentages of NPS nitrogen loads of various land use types are shown in Figure 4. It can be found that NPS nitrogen export varies in different land use types. The loads of agricultural land, construction land and unused land in the research area in 2005 were $92.04 \mathrm{t}, 969.28 \mathrm{t}$, and $21.77 \mathrm{t}$. It can be seen that the region with heavy NPS nitrogen pollution is construction land which accounted for $89.49 \%$ of the total load of the UABC.

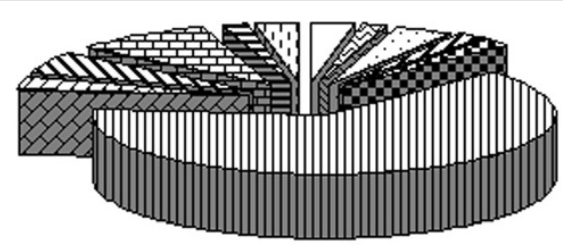

$\square$ plough
$\square$ woodland
$\square$ other farmland
$\square$ road
$\square$ land for transport
$\square$ unused land

$\otimes$ garden plot

$\square$ grassland

m building land (with roofs)

$\$$ independent industrial and mining area

$\Xi$ land for water conservation facilities

Figure 4 Percentages of NPS nitrogen loads of various land use types. 
Table 7 Spatial distribution of load intensity of NPS nitrogen in various regions

\begin{tabular}{llcc}
\hline No. & \multicolumn{1}{c}{ District } & $\begin{array}{c}\text { Load intensity of NPS } \\
\text { nitrogen }\left(\mathbf{k m}^{2} / \mathbf{t}\right)\end{array}$ & $\begin{array}{c}\text { Ratio to the average } \\
\text { value of UABC }\end{array}$ \\
\hline 1 & Xicheng district & 1.10 & 1.39 \\
2 & Dongcheng district & 1.11 & 1.41 \\
3 & Chaoyang district & 0.83 & 1.05 \\
4 & Haidian district & 0.67 & 0.85 \\
5 & Shijingshan district & 0.80 & 1.01 \\
6 & Fengtai district & 0.82 & 1.04 \\
7 & UABC & 0.79 & 1.00 \\
\hline
\end{tabular}

Large area and the high NPS nitrogen export are the reasons of heavy pollution in construction land. In the research, land for roofed buildings mean the land in which residential buildings, office buildings, or any other roofed buildings are constructed. Among the various types of construction lands, land for roofed buildings is the one output the most dominant pollution for its largest area and relatively high NPS nitrogen export. The pollution source of land for roofed buildings is the roof, which can't be swept routinely. NPS nitrogen accumulates in roofs during dry seasons and loses in rainfall events during wet seasons. Especially in the course of the first rainfall in a wet season, nitrogen pollutants accumulated for several months are scoured by roof runoff, which causes serious NPS nitrogen pollution in the UABC.

As for various land use types, spatial distributions of NPS nitrogen loads in them are shown in Table 6. The percentages of NPS nitrogen loads of various land use types are shown in Figure 4.

\section{Spatial distribution of load intensity of NPS nitrogen}

An important index of NPS pollution analyzing is load intensity, which means pollution load per unit area (such as $t / \mathrm{km}^{2}$ ) and can mitigate the effect of areas on loads). As for various administrative regions, spatial distribution of load intensity of NPS nitrogen is shown in Table 7 . Load intensity of NPS nitrogen is as shown Figure 5.

The high-load sources were distributed in the Xicheng district and Dongcheng district, human activities in which are much more intensive than those of other districts. The land use of the two districts include construction land exclusively, so it can be deduced that accumulated nitrogen pollutants in roofs and those in roads caused by exhaust gas emission are the main sources of NPS nitrogen. The lowest-load source is distributed in Haidian district. This could be explained by the fact that the percent of construction land in the total district area is $49.98 \%$, which is lower than that of any other districts. The load intensities of NPS nutrogen in other districts (i.e., Chaoyang district, Fengtai district and Shijingshan district) are in the middle level.

As for load intensity of NPS nitrogen in various land use types, the high-load source is distributed in construction land, which is the dominant one in the UABC. Large quantities of nitrogen pollutants are accumulated in building roofs and urban roads, which causes high load intensity of NPS nitrogen in construction land. The lowest-load source is agricultural land which could be explained by the fact that nitrogen export of it is relatively low due to the positive effect of soil and water conservation.

\section{Conclusions}

$\mathrm{UABC}$ is the most developed area in the city and has a very high population density. Sustained and cumulative human activities have serious impact on the process of nutrient accumulation and transportation. NPS pollution in urban areas has become the dominant factor affecting water quality of water bodies in Beijing City. The export coefficient model (ECM) can be used to calculate the

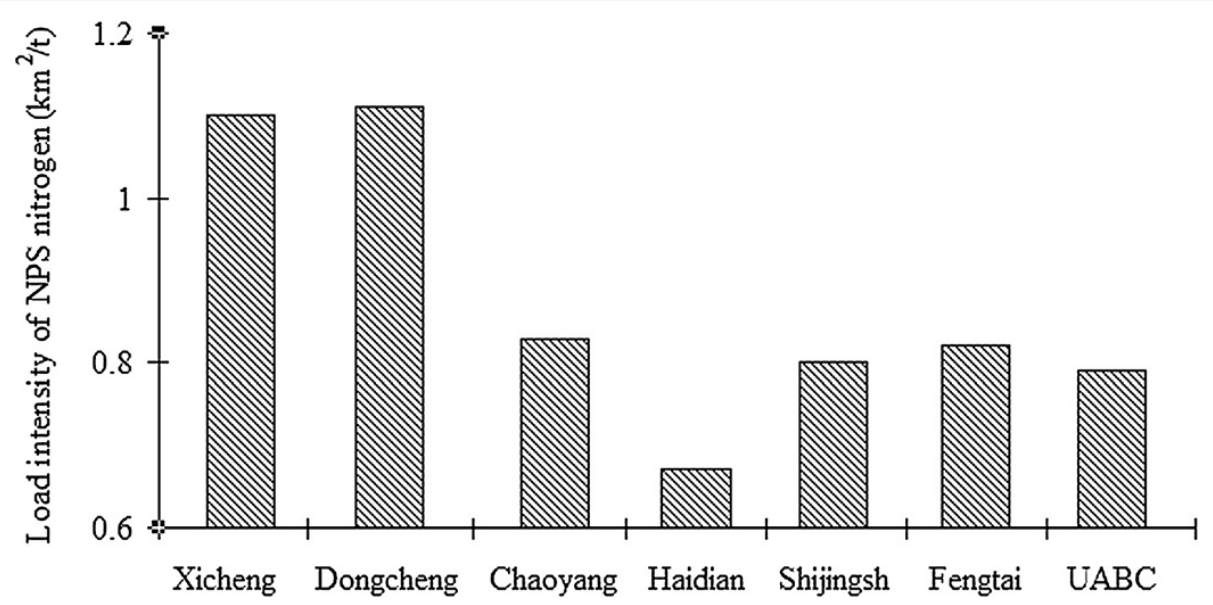

Figure 5 Load intensity of NPS nitrogen in various administrative regions. 
pollution load of NPS nitrogen and the export coefficients can be calibrated using the hydrology and water quality data. Take nitrogen as a typical NPS pollutant, annual load of NPS pollution was 1083.02 ton in 2005 . As for spatial distribution, Chaoyang district, Haidian district and Fengtai district are major regions carrying NPS nitrogen loads. Between various land use types, construction land is the one with heavy NPS nitrogen pollution. Among the various types of construction lands, land for roofed buildings carries the most dominant pollution. As far as various districts are concerned, high-load sources are distributed in the Xicheng district and Dongcheng district, and the lowest-load source is distributed in the Haidian district. As for load intensity of NPS nitrogen in various land use types, the high-load source was distributed in construction land, and lower percent of construction land results in lower load intensity of NPS nitrogen. So exhaust gas emission should be reduced, roof greening should be advanced, roof rainwater collection and processing should be promoted, and road sweep should be improved. In the future, analysis on pollution sources and cause factors in the study area should be advanced.

\section{Competing interests}

The authors declare that they have no competing interests.

\section{Authors' information}

${ }^{a}$ Key Laboratory of Urban Stormwater System and Water Environment (Beijing University of Civil Engineering and Architecture), Ministry of Education, No.1 Zhanlanguan Road, Beijing, P.R. China. 100044. ${ }^{\text {b Key }}$ Laboratory of Regional Energy and Environmental Systems Optimization, Ministry of Education, North China Electric Power University, No. 2 Beinong Road, Beijing, P.R. China. 102206. ' Institute for Energy, Environment and Sustainable Communities, University of Regina, 120, 2 Research Drive, Regina, Saskatchewan, Canada. S4S 7H9.

\section{Authors' contributions}

XD implemented the system architecture. She carried out the modeling and analyzed the model, results analysis and drafted the manuscript, which all the authors helped to edit and polish. YG provided data and discussed the system architecture. CA discussed and revised the manuscript. ML sorted the data and drew the figures. All the authors read and approved the final manuscript.

\section{Acknowledgements}

The work described in this study was funded by Open Research Fund Program of Key Laboratory of Urban Stormwater System and Water Environment (Beijing University of Civil Engineering and Architecture), Ministry of Education, as well as National Natural Science Foundation of China (No. 51309097).

\footnotetext{
Author details

'Key Laboratory of Urban Stormwater System and Water Environment, (Beijing University of Civil Engineering and Architecture), Ministry of Education, No.1 Zhanlanguan Road, Beijing 100044, People's Republic of China. ${ }^{2}$ Key Laboratory of Regional Energy and Environmental Systems Optimization, Ministry of Education, North China Electric Power University, No. 2 Beinong Road, Beijing 102206, People's Republic of China. ${ }^{3}$ Institute for Energy, Environment and Sustainable Communities, University of Regina, 120, 2 Research Drive, Regina, SK S4S 7H9, Canada.
}

\section{References}

Brown JN, Peake BM (2006) Source of heavy metals and polycyclic aromatic hydrocarbons in urban stormwater runoff. Water Sci Technol 25(8):13-19

Che W, Ou L, Wang HZ, Li JQ (2002) The quality and major influential factors of runoff in Beijing urban area. Tech Equip Environ Pollut Contr 3(1):33-37 (in Chinese)

Chimney MJ, Pietro KC (2006) Decomposition of macrophyte litter in a subtropical constructed wetland in south Florida (USA). Ecol Eng 27(4):301-321

Ding XW, Shen ZY, Hong Q, Yang ZF, Wu X, Liu RM (2010) Development and test of the export coefficient model in the upper reach of the Yangtze River. J Hydrol 383(3-4):233-244

Duzgoren ANS, Wong CSC, Songb ZG, Aydina A, Lic XD, Youb M (2006) Fate of heavy metal contaminants in road dusts and gully sediments in Guangzhou, SE China: a chemical and mineralogical assessment. Hum Ecol Risk Assess 12(2):374-389

Emili LA, Greene RP (2013) Modeling agricultural nonpoint source pollution using a geographic information system approach. Environ Manage 51(1):70-95

Jing HW (2008) The effect analysis of water eutrophication ameliorations in Liuhai lakes of Beijing. Beijing Water 1:7-10 (in Chinese)

Johnes PJ (1996) Evaluation and management of the impact of land use change on the nitrogen and phosphorus load delivered to surface waters: the export coefficient modelling approach. J Hydrol 183(3-4):323-349

Kang JH, Kayhanian M, Stensorm MK (2006) Implications of a kinematic wave model for first flush treatment design. Water Res 40(20):3820-3830

Kang OY, Lee SC, Wasewar K, Kim MJ, Liu HB, Oh TS, Janghorban E, Yoo CK (2013) Determination of key sensor locations for non-point pollutant sources management in sewer network. Korean J Chem Eng 30(1):20-26

Krometis LAH, Characklis GW, Simmons OD, Dilts MJ, Likirdopulos CA, Sobsey MD (2007) Intra-storm variability in microbial partitioning and microbial loading rates. Water Res 41(2):506-516

Leading group office of Beijing sixth national population census, Beijing Municipal Bureau of Statistics, Beijing survey office of National Bureau of Statistics of China (2011) Beijing sixth national population census data communique (in Chinese)

Liao RH, Ding YY, Hu XL, Chen JG, Zhang SH (2007) Analysis and evaluation of water quality of rainfall and runoff in urban area in Beijing. Beijing Water 1:14-16 (in Chinese)

Liu Y, Li JQ, Che W, Kuang R (2008) The urban runoff pollution control and "saving-power and decreasing-emission": Beijing as an example. Environ Pollut Contr 30(9):93-96 (in Chinese)

Rossi L, Fankhauser R, Chevre N (2006) Water quality criteria for total suspended solids in urban wet-weather discharges. Water Sci Technol 54(6-7):355-362

Sartor JD, Boyd GB, Agardy FJ (1972) Water pollution aspects of street surface contaminants. Water Pollut Contr Fed 46(3):458-467

Wada K, Yamanaka S, Yamamoto M, Toyooka K (2006) The characteristics and measuring technique of refractory dissolved organic substances in urban runoff. Water Sci Technol 53(2):193-201

Wang MM (2004) analysis and assessment of precipitation and runoff water quality in the southeast of Beijing urban area. Beijing University of Technology (in Chinese)

Wang XY (2011) Non point source pollution process mechanism and control management: taking Beijing watershed of Miyun Reservoir as an example. Sciences Press (in Chinese)

Ward NI (2004) Dudding LM (2004) Platinum emissions and levels in motorway dust samples: influence of traffic characteristics. Sci Total Environ 334-35:457-463

Whitehead PG, Heathwaite AL, Flynn NJ, Wade AJ, Quinn PF (2007) Evaluating the risk of non-point source pollution from biosolids: integrated modelling of nutrient losses at field and catchment scales. Hydrol Earth Syst Sci 11(1):601-613

doi:10.1186/2193-2697-2-12

Cite this article as: Ding et al:: Spatial distribution of non-point source nitrogen in urban area of Beijing City, China. Environmental Systems Research 2013 2:12. 